This is the version of the article accepted for publication in The Global Mindset. Advances in International Management published by Emerald doi:10.1016/S1571-5027(07)19002-1

Accepted version downloaded from SOAS Research Online: http://eprints.soas.ac.uk/32166

\title{
Global Mindset: A Review and Proposed Extensions ${ }^{1}$
}

Orly Levy, Sully Taylor, Nakiye A. Boyacigiller and Schon Beechler

\section{Cite as follows:}

Levy, O., S. Taylor, N. A. Boyacigiller, \& S. Beechler, (2007). Global mindset: A review and proposed extensions. In M. Javidan, R.M. Steers \& M. Hitt (Eds.), The Global Mindset. Advances in International Management. Vol. 19, Greenwich, CT: JAI Press: 11-47. 
This is the version of the article accepted for publication in The Global Mindset. Advances in International Management published by Emerald doi:10.1016/S1571-5027(07)19002-1

Accepted version downloaded from SOAS Research Online: http://eprints.soas.ac.uk/32166

\title{
Global Mindset: A Review and Proposed Extension
}

\author{
Orly Levy, Sully Taylor, Nakiye A. Boyacigiller and Schon Beechler
}

In the last ten years, global mindset has surfaced as a major long-term competitive advantage for firms competing in the global market arena. Increasingly, academics and practitioners have pointed to global mindset, or the cognitive capabilities of major decision makers, as critical to organizations because of its impact on a number of key organizational success factors (Gupta and Govindarajan, 2002; Murtha, Lenway and Bagozzi, 1998; Harveston, Kedia and Davis, 2000; Jeannet, 2000; Levy, 2005). In a dynamic, complex world driven by fierce global competition there has been a shift from structural and administrative competencies to mindset-based competencies (Bartlett and Ghoshal, 1990). As Govindarajan and Gupta (1998:2) so aptly put it: "Success is all in the [global] mindset."

The idea that the cognitive capabilities, or global mindset, of senior managers in multinational companies (MNCs) is central to organizational performance is not a new one; it dates back to early works by Aharoni (1966) and Kindleberger (1969) on foreign direct investment. Perlmutter (1969), however, was the first to focus attention specifically on managerial cognition in the literature by integrating senior executives' existing mindsets in his formal typology of MNCs.

Recent developments in the integration of the world economy and the immense complexity involved in managing current business realities have strengthened the focus on the cognitive aspects of MNCs (Doz and Prahalad, 1991; Prahalad, 1990). As globalization increases, MNCs are exposed to concurrent and often contradictory pressures for global integration and local responsiveness (Doz, Santos and Williamson, 2001; Prahalad and Doz, 1987; Bartlett and Ghoshal, 1990). Because of this, senior managers must coordinate and integrate geographically distant operations and a culturally diverse workforce (Bartlett and Ghoshal, 1990). Managers are also required to address local needs and to manage the varied inter-organizational relationships with a host of stakeholders, including customers, 
This is the version of the article accepted for publication in The Global Mindset. Advances in International Management published by Emerald doi:10.1016/S1571-5027(07)19002-1

Accepted version downloaded from SOAS Research Online: http://eprints.soas.ac.uk/32166

suppliers, strategic partners, and host country governments (Rosenzweig and Singh, 1991). Senior managers of MNCs must therefore find ways to balance opposing interests of function, business, and country (Murtha et al., 1998; Evans and Doz., 1992). In order to manage these demands, both practitioners and researchers propose that managers with a global mindset are better prepared for the complex multiple organizational environments, indeterminate structures, and heterogeneous cultures that characterize contemporary MNCs (Doz and Prahalad, 1991).

The increasing awareness that the cognitive element of MNCs is significant to firm development has produced a number of varying and often disparate definitions and frameworks but very limited empirical research in this field. Conceptually, phrases like "transnational mentality" (Bartlett and Ghoshal, 1989), "global mindset" (Rhinesmith, 1992), and "multinational mindset” (Caproni, Lenway and Murtha, 1992) have recently found favor in both academic and popular media. However, the characteristics of these concepts remain relatively ambiguous. Global mindset has become a term that denotes all things global or transnational, including individual attitudes, skills, competencies and behaviors, as well as organizational orientations, structures, strategies, policies and practices.

This paper analyzes and integrates the current thinking on global mindset, considering the significance that managerial cognition plays in MNCs' success. The following section reviews the existing research on global mindset and identifies two major dimensions that underlie the various writings regarding global mindset. Then, we evaluate the global mindset field as a whole and present our own conceptual model of global mindset and propose some illustrative theoretical propositions. To conclude, we summarize the major contributions of our approach.

\section{Literature Review}

In this section, we offer a careful and systematic review of the theoretical and empirical studies relating to global mindset that have been published in books and peer-reviewed journals to date. This 
This is the version of the article accepted for publication in The Global Mindset. Advances in International Management published by Emerald doi:10.1016/S1571-5027(07)19002-1

Accepted version downloaded from SOAS Research Online: http://eprints.soas.ac.uk/32166

review includes studies that use differing terms to refer to the idea of global mindset but consider the same general concept. At the same time, we exclude studies that do not specifically pertain to global mindset but concentrate on such areas as global leadership, expatriates, and expatriation, even though they may focus on similar underlying themes found in the global mindset literature. We then link the fundamental themes in the global mindset literature to cosmopolitanism and cognitive complexity - two influential theoretical constructs from the social sciences - and use these concepts to recommend a new integrative approach to global mindset.

We have found, in our review of the global mindset literature, that the majority of writers consider global mindset in relation to two salient dimensions of the global environment, specifically strategic complexity and/or national and cultural diversity. Thus, in the next section, we initially discuss Perlmutter (1969), whose work on geocentrism (global mindset) instigated subsequent research that focuses on the cultural aspect of global mindset. We label this first approach the cultural perspective, which it concentrates on the cultural distance and diversity related to global markets and operations and emphasizes the challenges integral to managing across national and cultural boundaries. We propose that cosmopolitanism, as well as the attitudes and perspectives that are associated with it, function as the fundamental premise of the cultural approach to global mindset.

Next, we present Bartlett and Ghoshal's (1989) theoretical approach and the related research on strategic complexity in international management. We label this approach the strategic perspective, which is derived from research on international strategy and concentrates on environmental complexity as well as the strategic variety arising from globalization. This perspective underscores the challenges inherent in managing multifaceted operations in geographically distant and strategically varied businesses while concurrently reacting to local conditions and needs (Prahalad and Doz, 1987). We 
This is the version of the article accepted for publication in The Global Mindset. Advances in International Management published by Emerald doi:10.1016/S1571-5027(07)19002-1

Accepted version downloaded from SOAS Research Online: http://eprints.soas.ac.uk/32166

suggest that this body of work draws on cognitive complexity and its related capabilities in conceptualizing global mindset.

In the third and final section of our literature review, we present the multidimensional perspective. The work of Rhinesmith $(1992,1993,1996)$ acts as the foundation for this body of work and here global mindset is conceptualized in both cultural and strategic terms while incorporating a host of additional characteristics, as we discuss below.

\section{The Cultural Perspective}

Research in the cultural school of thought considers global mindset from within the context of the cultural diversity inherent to the process of globalization. According to this perspective, senior managers are increasingly faced with the challenge of prevailing over domestic myopia and an ethnocentric mindset, traversing cultural boundaries, interacting with employees from many countries, and managing culturally divergent inter-organizational relationships. The cultural perspective suggests that the way to manage these challenges effectively is to retreat from an ethnocentric mindset and cultivate a global mindset—one that includes cultural self-awareness, openness to and understanding of other cultures, and selective incorporation of foreign values and practices.

The cultural perspective uses Perlmutter's (1969) revolutionary tripartite typology of managerial mindsets in MNCs as a conceptual foundation. Diverging from previous work in international business, Perlmutter and his colleagues (Perlmutter, 1969; Heenan and Perlmutter, 1979; Chakravarthy and Perlmutter, 1985) suggest a typology of MNCs specifically based on senior executives' mindsets. Initially, Perlmutter (1969) made a distinction between three principal states of mind, or attitudes, toward managing a multinational enterprise: ethnocentric (home-country orientation), polycentric (hostcountry orientation), and geocentric (world-orientation). Perlmutter proposed that these orientations affect and mold various characteristics of the multinational enterprise, including structural design, 
This is the version of the article accepted for publication in The Global Mindset. Advances in International Management published by Emerald doi:10.1016/S1571-5027(07)19002-1

Accepted version downloaded from SOAS Research Online: http://eprints.soas.ac.uk/32166

strategy and resource allocation, and, in particular, management mindset and processes. Managers with a geocentric orientation, or a global mindset, exhibit universalistic, supra-national approaches, deemphasizing the importance of cultural distinction and nationality when deciding who is capable or reliable (Perlmutter 1969). Superiority and nationality are not considered as equivalent since "good ideas come from any country and go to any country within the firm," (Heenan and Perlmutter, 1979: 2021).

Perlmutter's description of geocentrism acts as an foundation for many of the current conceptualizations of global mindset which concentrate on the challenge of overcoming embedded ethnocentrism and rising above nationally-entrenched views (e.g., Maznevski and Lane, 2004; Doz, et al., 2001; Adler and Bartholomew, 1992a; Estienne, 1997). For example, Maznevski and Lane (2004) describe global mindset as a meta-capability typified by two corresponding facets: an inclusive cognitive structure that directs attention and interpretation of information and a well-developed competence for altering and revising this cognitive structure with new experiences. They define global mindset as "the ability to develop and interpret criteria for personal and business performance that are independent from the assumptions of a single country, culture, or context; and to implement those criteria appropriately in different countries, cultures, and contexts" (Maznevski and Lane, 2004:172). The notion that going beyond national borders and developing complex cultural knowledge is vital for firm success is also central to Adler and Bartholomew's (1992a) discussion of the "transnational manager." They assert that while the traditional international manager views the world from a single-country perspective, the transnational manager has a global perspective characterized by knowledge of, and appreciation for, many foreign cultures. In addition to focusing on perspectives, research within the cultural perspective stream often discusses global mindset in terms of cross-cultural skills and abilities (Adler and Bartholomew, 1992a; Estienne, 1997). ${ }^{2}$ 
This is the version of the article accepted for publication in The Global Mindset. Advances in International Management published by Emerald doi:10.1016/S1571-5027(07)19002-1

Accepted version downloaded from SOAS Research Online: http://eprints.soas.ac.uk/32166

Kobrin (1994) conducted the first empirical study that explicitly examined the construct of geocentrism, or global mindset, as defined by Heenan and Perlmutter (1979). He examined the popular supposition that firms with a global, integrated strategy and/or a global organizational structure will have a geocentric mindset. Kobrin concludes from his research results that while there is an association between a geocentric mindset and the geographic scope of the firm, the direction of causality is not clear. He proposes that global mindset should be considered a multidimensional construct rather than a unidimensional reflection of firm-level characteristics. Several recent studies (Beechler, Levy, Taylor and Boyacigiller, 2004; Taylor, Levy, Boyacigiller and Beechler, forthcoming) also demonstrate that employees' perceptions of geocentrism are positively related to organizational commitment.

\section{An Underlying Dimension of the Cultural Perspective: Cosmopolitanism}

Reviewing the literature on global mindset within the cultural perspective, we find that while most writers do not specifically cite the construct, cosmopolitanism, and the attitudinal approach coupled with it, serves as an underlying theme of the cultural stance to global mindset, and therefore should be considered to be one of the major conceptual dimensions of the global mindset construct.

Cosmopolitanism, and the distinction between cosmopolitans and locals, first appeared in the social sciences over fifty years ago (Merton, 1957; Gouldner, 1957) ${ }^{3}$ After having fallen out of favor for a period of time, cosmopolitanism has staged a comeback in the 1990s with the increased development and proliferation of global systems and transnational cultures (see Hannerz, 1996; Harvey, 2000; Beck, 2000; Breckenridge, Pollock, Bhabha, and Chakrabarty, 2000; Vertovec and Cohen, 2002a; Archibugi, 2003). ${ }^{4}$ In their appraisal of recent work on cosmopolitanism, Vertovec and Cohen (2002b:4) propose that cosmopolitanism simultaneously: (a) transcends the nation-state model; (b) reconciles actions and ideals that slant both to the universal and the particular, the global and the local; 
This is the version of the article accepted for publication in The Global Mindset. Advances in International Management published by Emerald doi:10.1016/S1571-5027(07)19002-1

Accepted version downloaded from SOAS Research Online: http://eprints.soas.ac.uk/32166

(c) is in opposition to cultural essentialism; and (d) embodies a variety of complex repertoires of identity, interest, and allegiance.

On a more individual or personal level, cosmopolitanism signifies a “...perspective, a state of mind, or - to take a more process-oriented view — a mode of managing meaning" (Hannerz, 1996:102). "Genuine" cosmopolitans are identified by their "willingness to engage with the Other... openness toward divergent cultural experiences, a search for contrasts rather than uniformity...." (Hannerz, 1996:163; italics added). Simultaneously, however, cosmopolitanism has been defined as “... a matter of competence... a personal ability to make one's way into other cultures, through listening, looking, intuiting, and reflecting" (Hannerz, 1996:193). Even though cosmopolitans are often travelers by nature and are generally engaged with global systems and transnational cultures, many writers suggest that “...it is not travel that defines cosmopolitans—-some widely traveled people remain hopelessly parochial-it is mindset" (Kanter, 1995:23). ${ }^{5}$

In our framework, cosmopolitanism represents a state of mind that is focused toward the outside, the Other, and works to both unite the local with the global as well as the well-known and the foreign. A second crucial characteristic of cosmopolitanism is openness, an eagerness to investigate and learn from others' meaning systems. Collectively, these two characteristics act as the foundation for the cultural perspective in the literature regarding global mindset.

\section{The Strategic Perspective}

While the studies reviewed above all highlight the significance of recognizing cultural diversity and transcending national borders, studies framing global mindset through a strategic lens consider global mindset in terms of the increased complexity produced by globalization. MNCs are faced with the challenge of successfully managing environmental and strategic complexity and incorporating geographically distant operations and markets, while concurrently 
This is the version of the article accepted for publication in The Global Mindset. Advances in International Management published by Emerald doi:10.1016/S1571-5027(07)19002-1

Accepted version downloaded from SOAS Research Online: http://eprints.soas.ac.uk/32166

acting in response to local demands (Prahalad and Doz, 1987; Prahalad, 1990; Kim and Mauborgne, 1996; Sanders and Carpenter, 1998). The strategic perspective on global mindset is founded in international strategy research that was conducted at Harvard in the 1970s and 1980s, particularly the innovative research of Bartlett and Ghoshal $(1989,1990,1992)$. Bartlett and Ghoshal classify the transnational organization as the ideal organization, which is not a distinct strategic stance or a specific organizational model but is rather a new management mentality that "recognize(s) that environmental demands and opportunities vary widely from country to country...(and) also recognize(s) that different parts of the company possess different capabilities" (Bartlett and Ghoshal, 1989:64).

The literature in the strategic perspective category is founded on the assertion that the increased complexity, heterogeneity, and indeterminacy of MNCs (Doz and Prahalad, 1991) can no longer be managed by structural and administrative mechanisms (Prahalad and Bettis, 1986; Doz and Prahalad, 1991; Evans, Pucik and Barsoux, 2002). Accordingly, this perspective proposes that the key determinant of strategic capabilities of an MNC lies in cultivating a complex managerial mindset (e.g., Bartlett and Ghoshal, 1989; Caproni, et al., 1992; Murtha, et al., 1998; Paul, 2000). Thus, the properties of global mindset are depicted in terms of high cognitive abilities and information processing capabilities that allow managers to understand complex global dynamics (e.g., Jeannet, 2000; Tichy, Brimm, Charan, and Takeuchi, 1992), balance between competing demands and concerns (e.g., Murtha, et al., 1998; Begley and Boyd, 2003), reconcile the tensions between the local and the global (e.g., Kefalas, 1998; Arora, Jaju, Kefalas, and Perenich, 2004), differentiate between and integrate across cultures and markets (e.g., Govindarajan and Gupta, 2001; Gupta and Govindarajan, 2002), and examine and attend to global issues (e.g., Rhinesmith, 1993; Levy, 2005; Bouquet, 2005). 
This is the version of the article accepted for publication in The Global Mindset. Advances in International Management published by Emerald doi:10.1016/S1571-5027(07)19002-1

Accepted version downloaded from SOAS Research Online: http://eprints.soas.ac.uk/32166

In defining global mindset, for instance, Jeannet (2000:11) underscores the capacity to assimilate across domains: "[global mindset is] ... a state of mind able to understand a business, an industry sector, or a particular market on a global basis. The executive with a global mindset has the ability to see across multiple territories and focuses on commonalities across many markets rather than emphasizing the differences among countries." Jeannet points to a number of essential components of global mindset: evaluating global markets, assessing globalization pathways, and offering a sufficient strategic response. Jeannet suggests that global mindset is not solely a linear extension of the multinational mindset; it diverges significantly in terms of thinking patterns, responses, and cognitive skills. Jeannet (2000) also employs the notion of global mindset at the corporate level, defining it as "those cultural aspects of a company that define the extent to which the firm has learned to think, behave, and operate in global terms" (Jeannet, 2000: 199). He asserts that even having a pool of managers that possess a global mindset is not sufficient if a company's structure, processes, and behavior do not also support the same principles.

While some authors (Jeannet, 2000; Tichy et al., 1992) characterize global mindset in relation to managers' abilities to appreciate, distinguish, and integrate across complex global dynamics, a few studies within the strategic perspective group focus on effectively balancing global integration with local responsiveness (e.g., Murtha, et al., 1998; Begley and Boyd, 2003) or on reconciling the tension between "thinking globally" and "acting locally" (e.g., Kefalas, 1998; Arora, et al., 2004). Murtha et al. (1998), for example, depict global mindset as the "cognitive processes that balance competing country, business, and functional concerns" and assess the correlation between global mindset and cognitive shift. In their study, Murtha et al. (1998) observe that the transformation in global strategy of a major MNC brought about a cognitive shift among managers in the organization toward a more global mindset. Begley and Boyd (2003) similarly focus on mediating the tension between the global and the local, analyzing global 
This is the version of the article accepted for publication in The Global Mindset. Advances in International Management published by Emerald doi:10.1016/S1571-5027(07)19002-1

Accepted version downloaded from SOAS Research Online: http://eprints.soas.ac.uk/32166

mindset at the corporate level. Echoing Jeannet (2000), Begley and Boyd (2003) contend that in order to embed global mindset on an organization-wide level, supporting policies and practices must be in place to manage tensions relating to structural (global formalization vs. local flexibility), processual (global standardization vs. local customization), and power (global dictates vs. local delegation) concerns. Likewise, Kefalas (1998) and Arora et al. (2004) focus on the tension between "thinking globally" and "acting locally." Kefalas maintains that global mindset is typified by high levels of both conceptualization (the expression of fundamental ideas that depict a phenomenon, and the identification of the major relationships between these ideas and the whole) and contextualization (the adaptation of a conceptual framework to the local environment) abilities (Kefalas, 1998; Arora, et al., 2004).

Utilizing Kefalas and colleagues' approach to global mindset (e.g., Kefalas, 1998; Kefalas and Neuland, 1997; Kefalas and Weatherly, 1998), Arora et al. (2004) observe that managers are more adept at thinking globally (conceptualization) than they are at acting locally (contextualization). Their study also shows that of all demographic characteristics, training in international management, manager's age, foreign country living experience, family member from a foreign country, and job experience in a foreign country have proven to have the most statistically significant impacts on managers' global mindset.

Govindarajan and Gupta (2001) and Gupta and Govindarajan (2002) similarly consider the capacity to concurrently take local cultures and markets and global dynamics into account when making decisions as the central attribute of global mindset. They define global mindset as a knowledge structure that exemplifies both high differentiation and high integration, and "...one that combines an openness to and awareness of diversity across cultures and markets with a propensity and ability to synthesize across this diversity" (Govindarajan and Gupta, 2001:111). These authors characterize global mindset at the corporate level as the combined global mindset of individuals that is then adjusted for the distribution of 
This is the version of the article accepted for publication in The Global Mindset. Advances in International Management published by Emerald doi:10.1016/S1571-5027(07)19002-1

Accepted version downloaded from SOAS Research Online: http://eprints.soas.ac.uk/32166

power and mutual influence among the group. Govindarajan and Gupta (2001) concede that the highest returns to investment in developing a global mindset will derive from a stronger focus on senior level managers. Nonetheless, their unequivocal advice is that if a company's goal is to secure and maintain global market leadership in its industry, it must strive to develop a global mindset in every unit and every employee.

Three recent empirical studies (e.g., Harveston, et al., 2000; Nummela, Saarenketo, and Puumalainen, 2004; Bouquet, 2005) study the relationship between firm strategic position, market characteristics, and global mindset. Harveston and colleagues observe that managers in firms that are "born global" have a stronger global mindset, more international experience and higher risk tolerance than managers of gradually globalizing firms. Likewise, Nummela et al. (2004) demonstrate that market characteristics - the level of globalization of the market in which the firm operates and the turbulence of the market—are positively related to global mindset; management experience, measured as international work experience, is also positively related to global mindset, while international education is not.

Finally, Bouquet (2005) considers the relationship between the top management team's (TMT) decision environment and TMT global mindset. He depicts global mindset as an awareness of global strategic issues, and identifies attention as the key component and, therefore, the primary expression of global mindset. He hypothesizes that global attention structures (for example, structural positions related to globalization and/or global meetings), which firms establish in order to regulate the distribution of attention of managers in the firm, will mediate the relationship between firms' decision environments and TMT attention. Bouquet's (2005) research empirically supports the hypothesized relationships. Moreover, the results demonstrate a concave relationship between TMT attention to global issues and firm performance. He (2005) concludes that both inadequate and excessive amounts of TMT 
This is the version of the article accepted for publication in The Global Mindset. Advances in International Management published by Emerald doi:10.1016/S1571-5027(07)19002-1

Accepted version downloaded from SOAS Research Online: http://eprints.soas.ac.uk/32166

attention to global strategic issues can have a negative impact on firm performance; in other words, contrary to accepted wisdom, more global mindset is not always better.

In contrast to the above studies that examine the relationship between a firm's characteristics and global mindset, Levy (2005) analyzes the relationship between TMT attentional patterns, deemed a primary manifestation of global mindset, and a firm's global strategic position. She finds consistent support for the proposition linking TMT attentional patterns, concluding that firms are more likely to be highly global when their top management focuses on the global environment and takes a diverse set of this environment's elements into account.

Other relevant studies at the top management team level used background characteristics of team members, especially international experience, as a proxy for a broad definition of global mindset: “...international experience may be a surrogate for cultural knowledge or a global mind set which captures the skills necessary for successfully formulating and implementing an international strategy" (Peyrefitte, Fadil, and Thomas, 2002: 496). The underlying premise is that international experience exposes executives to different cultures, value systems, languages, and institutional environments (Carpenter, Sanders and Gregersen, 2001) as well as to diverse information and knowledge sources. This exposure results in superior cross-cultural and cognitive abilities or "new ways of learning and responding to stimuli because of socio-cultural differences" (Ricks, Toyne and Martinez, 1990: 220). These studies examine the relationship between international experience and a variety of organizational outcomes, including internationalization (Sambharya, 1996; Reuber and Fischer, 1997; Tihanyi, Ellstrand, Daily and Dalton, 2000; Carpenter and Fredrickson, 2001; Athanassiou and Nigh, 2002; Peyrefitte et al., 2002; Tseng, Tansuhaj and Rose, 2004; Caligiuri, Lazarova and Zehetbauer, 2004), financial performance (Roth, 1995; Daily, Certo and Dalton, 2000; Carpenter et al., 2001), choice of entry mode (Herrmann and Datta, 2002), and learning (Yeoh, 2004). For example, Sambharya (1996), 
This is the version of the article accepted for publication in The Global Mindset. Advances in International Management published by Emerald doi:10.1016/S1571-5027(07)19002-1

Accepted version downloaded from SOAS Research Online: http://eprints.soas.ac.uk/32166

Reuber and Fischer (1997), Tihanyi et al. (2000), Carpenter et al. (2001), Athanassiou and Nigh (2002), Peyrefitte et al. (2002) and Tseng et al. (2004) find a positive relationship between international experience of top management and internationalization. However, Athanassiou and Nigh (2002) find that the impact of international experience of each individual TMT member on internationalization is not equal, but rather weighted by his or her centrality within the team. Thus, international experience counts for more or less, depending on the structural position of the individual team member (Athanassiou and Nigh, 2002). Similarly Caligiuri et al. (2004) also focus on internationalization, but use national diversity of TMT as an indicator of international experience rather than individual international experience. They observe a positive relationship between national diversity of TMT and internationalization. Daily et al. (2000) and Carpenter et al. (2001) find a positive association between international experience of senior executives and firm's financial performance. Daily et al. (2000) also note that the degree of internationalization of the firm moderates the relationship between international experience and performance. While Roth (1995) observes that international experience measured in terms of managing international activities has no direct or interactive effect on performance, international experience measured by overseas assignments has a direct effect when there is a high degree of internationalization and a negative effect when there is a low degree of internationalization.

\section{An Underlying Dimension of the Strategic Perspective: Cognitive Complexity}

Although it is rarely overtly mentioned in the literature, cognitive complexity and the cognitive capabilities associated with it serve as an underlying theme of the strategic perspective to global mindset, and should therefore be considered a second major conceptual dimension of global mindset. Research on cognitive complexity dates back more than forty years (e.g., Bieri, 1955; Harvey, Hunt, and Schroder, 1961; Schroder, Driver, and Streufert, 1967; Schroder and Suedfeld, 1971; Streufert and Nogami, 1989; Streufert, Pogash, and Piasecki, 1988; Streufert and Streufert, 1978; Streufert and 
This is the version of the article accepted for publication in The Global Mindset. Advances in International Management published by Emerald doi:10.1016/S1571-5027(07)19002-1

Accepted version downloaded from SOAS Research Online: http://eprints.soas.ac.uk/32166

Swezey, 1986). In the realm of management, the complexity of managerial cognition has been accepted for quite some time as a major factor impacting decision-making, strategic choice, and organizational performance (Weick, 1979; Kiesler and Sproull, 1982; Bartunek, Gordon and Weathersby, 1983; Schwenk, 1984; Duhaime and Schwenk, 1985; Ginsberg, 1990; Miller, 1993).

Cognitive complexity signifies the degree of differentiation, articulation, and integration within a cognitive structure (Bartunek et al., 1983; Weick and Bougon, 1986). In other words, a cognitive structure composed of a relatively large number of well-integrated and finely articulated components is considered relatively complex. Whereas cognitive complexity generally denotes the structural dimension of a cognitive structure (i.e., the internal organization of information units), the structural and content (i.e., specific information units or knowledge) dimensions become intertwined when considering cognitive complexity in relation to a specific information domain. To be more precise, an individual is unable to form a complex representation of the information domain without sufficient knowledge. Thus, our conceptualization of cognitive complexity comprises both the structural and knowledge dimensions that are essential to form complex representation and understanding.

Studies on cognitive complexity have routinely found that cognitively complex individuals have more advanced information processing capabilities. Cognitively complex people seek out more extensive and original information (Dollinger, 1984; Karlins and Lamm, 1967; Streufert and Swezey, 1986), spend more time interpreting it (Dollinger, 1984; Sieber and Lanzetta, 1964), identify a larger number of dimensions, and concurrently are able to possess and employ a number of opposing and complementary explanations (Bartunek, et al., 1983). In the multinational context, for instance, cognitive complexity is necessary in order to simultaneously balance the often conflicting demands of global integration and local responsiveness. Cognitive complexity has also been associated with a tolerance for ambiguity (Streufert, Streufert and Castore, 1968), an ability to have more well-rounded 
This is the version of the article accepted for publication in The Global Mindset. Advances in International Management published by Emerald doi:10.1016/S1571-5027(07)19002-1

Accepted version downloaded from SOAS Research Online: http://eprints.soas.ac.uk/32166

impressions (Streufert and Swezey, 1986), a capacity to reframe problems (Lepsinger, Mullen, Stumpf and Wall, 1989; Merron, Fisher and Torbert, 1987), an ability to balance contradictions,), and a consideration of more alternative points of view (Chang and McDaniel, 1995). Together, these works confirm the importance of cognitive complexity, and subsequently, to the damaging consequences of cognitive simplicity in a complex, rapidly changing world.

\section{The Multidimensional Perspective}

In addition to the two major schools of thought in the global mindset literature described above, a third category of research in the global mindset literature integrates both the cultural and strategic dimensions, augmenting them with several additional attributes. The research utilizing the multidimensional perspective, increasingly manifest in the literature beginning in 1994, has been profoundly influenced by the work of Rhinesmith $(1992,1993,1996)$, whose description of global mindset blends concepts from both the cultural and strategic perspectives. Rhinesmith defines mindset as "a way of being, not a set of skills... It is an orientation to the world that allows you to see certain things that others do not see. A 'global' mindset means that we scan the world from a broad perspective, always looking for unexpected trends and opportunities" (Rhinesmith, 1992: 63). Rhinesmith (1992:64) contends that people with global mindsets are more inclined to search for the broader context, accept life as a balance of conflicting forces, and have more confidence in organizational processes than in organizational structure. They hold diversity in high regard, are not threatened by surprises or uncertainty, and aspire to be open to themselves and others. According to Rhinesmith, global mindset thus involves high levels of cognitive capabilities, particularly those involving scanning and information processing, in addition to the capacity to integrate competing realities and demands and the ability to value cultural diversity. Rhinesmith's approach to global mindset epitomizes a multidimensional perspective, as he integrates not only cultural and strategic 
This is the version of the article accepted for publication in The Global Mindset. Advances in International Management published by Emerald doi:10.1016/S1571-5027(07)19002-1

Accepted version downloaded from SOAS Research Online: http://eprints.soas.ac.uk/32166

dimensions but also focuses on individual characteristics, as drawn from the literature on global leadership, into his discussion.

Much of the research in the multidimensional perspective category builds directly on Rhinesmith's work (Ashkenas, Ulrich, Jick and Kerr, 1995; Srinivas, 1995; Neff, 1995; Kedia and Mukherji, 1999; Paul, 2000). In addition to describing global mindset in terms of the capacity to distinguish and comprehend complex and often unanticipated business, cultural, and geopolitical dynamics, authors employing the multidimensional perspective cite a variety of characteristics when describing global mindset. For example, Kedia and Mukherji (1999) assert that global mindset is distinguished by openness and a capacity to identify complex interrelationships. Using the foundation created by Rhinesmith (1993) and Kefalas and Neuland (1997), Kedia and Mukherji (1999) contend that the three key components that distinguish a global mindset are: (1) a unique time perspective; (2) a unique space perspective; and (3) a general predisposition to be open-minded towards other peoples and cultures, to think of cultural diversity as an asset, to thrive on ambiguity, to balance conflicting viewpoints and demands, and to reframe boundaries (Kedia and Mukherji, 1999). In addition, Kedia and Mukherji make use of work in the global leadership literature, noting that global mindset also consists of an emotional connection, a capacity to balance conflicting tensions, an aptitude for managing ambiguity, and savvy (Gregersen, Morrison and Black, 1998). Furthermore, they maintain that managers need both a global mindset and a specific supportive skill and knowledge set in order to be globally effective.

\section{Discussion}

As demonstrated in the literature review, current views on global mindset can be organized into cultural, strategic, and multidimensional perspectives. There is inconsistency both within and across these perspectives, however, and conceptual opacity in the field as a whole. Definitions and the global 
This is the version of the article accepted for publication in The Global Mindset. Advances in International Management published by Emerald doi:10.1016/S1571-5027(07)19002-1

Accepted version downloaded from SOAS Research Online: http://eprints.soas.ac.uk/32166

mindset construct vary extensively throughout the research, as do the intensity of analysis, and the operationalization of global mindset. Empirical studies additionally have encountered conflicting and paradoxical findings. Due to this multiplicity of results and viewpoints, we present a critical reading of the literature as a first step toward creating a thorough and more theoretically-grounded research agenda.

The core properties of global mindset. The greatest discrepancy in the current literature involves the core properties of global mindset. The above literature review reveals that studies offer diverse definitions for global mindset. Its central characteristics are described in three, somewhat discrete, sets of terms. The first set of terms is cognitive, where studies describe the core properties of global mindset using cognitive and information-processing terms. Some examples are "knowledge structure," "cognitive structure," "ability to develop and interpret," "attention," "sensemaking," and "conceptualization and contextualization abilities." The second set of descriptors is existentialist; these studies classify global mindset using terms in the vein of a "way of being," "state of mind," “orientation," "openness," and "awareness," although a thorough reading of these classifications also reveals a strong cognitive foundation. The third set of terms authors use to portray global mindset is behavioral, where studies describe global mindset in behavioral, dispositional, and competency-related terms such as "propensity to engage," "ability to adapt," "curiosity," and "seeking opportunities," to name a few. Clearly, this multiplicity of terms and perspectives on global mindset, which employ diverse and discrete theoretical and research perspectives, is a significant challenge for theoretical integration of the field.

Dimensionality of global mindset. Global mindset has been characterized and evaluated both as a unidimensional and a multidimensional construct, as depicted in the literature review above. The unidimensional conceptualizations principally concentrate on the cross-cultural features of global mindset. Conversely, the multidimensional approaches, which often employ the international strategy 
This is the version of the article accepted for publication in The Global Mindset. Advances in International Management published by Emerald doi:10.1016/S1571-5027(07)19002-1

Accepted version downloaded from SOAS Research Online: http://eprints.soas.ac.uk/32166

literature in their discussions, consider global mindset in the scope of MNCs' localization and integration challenges. ${ }^{6}$ In this paper, we maintain that there are two principal dimensions-cultural and strategic - that should be considered in the characterization and evaluations of global mindset. Furthermore, the multidimensionality and level of complexity of the global environment indicates that global mindset should be conceptualized as a multidimensional construct.

Level of analysis. Studies on global mindset have been carried out at several levels of analysis (i.e., individual, group, and organization). Therefore, global mindset as represented in the current literature can tentatively be deemed a multilevel construct, subsequently involving both conceptual and methodological concerns particular to multilevel research (see Rousseau, 1985 for a discussion of methodological issues that arise from multi-level research). While there are a variety of perspectives, there is a surprising lack of debate on this issue of multilevel analysis; one of the fundamental questions emphasized by our literature review is therefore whether or not global mindset can indeed be considered an attribute of individuals, groups, and organizations. An additional related question is whether the global mindset constructs posited and evaluated at different levels are isomorphic, partially identical, or only weakly related (Rousseau, 1985). ${ }^{7}$ For instance, researchers often mention individual and organizational global mindsets (Govindarajan and Gupta, 1998; Bartlett and Ghoshal, 1989), but do not answer the question of whether these constructs are identical across levels.

Operationalization of global mindset. Operationalization of global mindset is yet another area of methodological concern. Global mindset has been operationalized using varied measures and data sources, both from across and within theoretical levels, in some instances as a unidimensional construct and in others as a multidimensional construct. Evaluation at the individual level utilizes self-report questionnaires assessing two key measures: individual preferences and attitudes (Arora, et al., 2004; Gupta and Govindarajan, 2002) and individual expectations about the MNC's global strategy (Murtha, 
This is the version of the article accepted for publication in The Global Mindset. Advances in International Management published by Emerald doi:10.1016/S1571-5027(07)19002-1

Accepted version downloaded from SOAS Research Online: http://eprints.soas.ac.uk/32166

et al., 1998). At the team level, studies employ textual and behavioral measures of top management team global mindset (Levy, 2005; Bouquet, 2005); and studies at the organizational level develop perceptual data of globalization-related organizational policies and practices (Kobrin, 1994; Gupta and Govindarajan, 2002).

This range of measures, which reveals the conceptual heterogeneity and ambiguity discussed earlier, necessitates a critical evaluation of the validity of the content and construct in several measures at each level of analysis (level-specific validity). Generally, instituting content validity would entail identifying the pertinent content domain of global mindset at each level of analysis. Establishing construct validity, alternatively, would involve constructing and clarifying a theoretical network of constructs — antecedents and/or outcomes — that involve global mindset in a consistent, theoretically predicted manner (Carmines and Zeller, 1979). ${ }^{8}$ These theoretical specifications may prove to be extremely challenging to define for an abstract construct such as global mindset. Even so, a critical first step toward guaranteeing a sufficient level-specific operationalization of global mindset would be to plot the appropriate universe of content that defines global mindset at each theoretical level, and to clarify the theoretical relationships between global mindset and its antecedents and/or outcomes.

Empirical research. While there have been very few empirical studies of global mindset to date, our literature review denotes the multiplicity of perspectives taken by researchers. Furthermore, because of this diversity and inconsistent and conflicting use of definitions and operationalizations of global mindset, only a handful of conclusions can be derived regarding the empirical relationships between global mindset and other individual- or organizational-level variables. One of the most fundamental questions, for instance, is whether global mindset precedes strategy and structure or vise versa. Levy (2005) observes a significant relationship between global mindset and global strategy, concluding that TMT global mindset drives globalization. Research that investigates the relationship 
This is the version of the article accepted for publication in The Global Mindset. Advances in International Management published by Emerald doi:10.1016/S1571-5027(07)19002-1

Accepted version downloaded from SOAS Research Online: http://eprints.soas.ac.uk/32166

between international experience and internationalization has produced comparable conclusions (e.g., Sambharya, 1996; Reuber and Fischer 1997; Tihanyi et al., 2000; Carpenter and Fredrickson, 2001; Athanassiou and Nigh, 2002 ; Peyrefitte et al., 2002; Tseng et al., 2004). In contrast, works by Murtha et al. (1998), Nummela et al. (2004), and Harveston et al. (2000) demonstrate that managerial global mindset follows strategy, rather than the other way around. Another study by Bouquet (2005) proposes that the relationship between TMT global mindset and firm characteristics is decided by firms' attention structures and that the association between these characteristics and global mindset is complicated. Lastly, and divergent from the other findings described above, Kobrin (1994) and Arora et al. (2004) conclude that global mindset is not at all related to firm characteristics.

An additional significant question at the organizational level involves the effect that global mindset has on firm performance. The evidence regarding this matter is slight and once again contradictory. Nummela et al. (2004) uncover a positive relationship between global mindset and financial indicators of the international performance of firms; meanwhile, they discover no noteworthy relationship between global mindset and managers' subjective evaluations of performance. Daily et al. (2000) and Carpenter et al. (2001) find a positive correlation between international experience of senior executives and firm's financial performance. At the same time, Daily et al. (2000) and Roth (1995) observe that the relationship between international experience and performance is mediated by the firm's degree of internationalization. Bouquet (2005), in contrast, finds a curvilinear relationship between TMT attention to global issues and firm performance.

As a final point, surprisingly little is understood regarding the empirical relationship between global mindset and individual characteristics. Although a small number of writers in the field of global leadership investigate this matter (e.g., McCall and Hollenbeck, 2002; Maznevski and Lane, 2004), Arora et al. (2004) offer the only evidence that individual characteristics such as foreign country job, 
This is the version of the article accepted for publication in The Global Mindset. Advances in International Management published by Emerald doi:10.1016/S1571-5027(07)19002-1

Accepted version downloaded from SOAS Research Online: http://eprints.soas.ac.uk/32166

foreign country living experience, and international management training are correlated with managers' global mindset. Nummela et al. (2004) present tangential evidence on this relationship, with their discovery that TMT international work experience is positively related to global mindset, while TMT international education is not related to global mindset.

\section{Global Mindset, Information Processing, and Managerial Performance:}

\section{An Integrative Framework}

In this section of the chapter, we suggest an approach to global mindset that incorporates concepts from the literature reviewed above, employing the fundamental constructs of both cosmopolitanism and cognitive complexity. We deliberately focus our discussion on global mindset at the individual level of analysis and define it at this level. We additionally, however, discuss global mindset at the group and organizational levels and propose that it can be considered across multiple levels. Furthermore, although we recognize that others have incorporated a number of skills and traits in their characterizations of global mindset, we focus chiefly on the cognitive properties of global mindset because we consider them to be the construct's most fundamental elements.

\section{Defining Global Mindset}

We regard global mindset as an individual-level construct that describes and signifies a distinctive multidimensional cognition. We therefore view global mindset as an individual-level cognitive structure or, in more general terms, as a knowledge structure. We define global mindset as $a$ highly complex cognitive structure distinguished by an openness to and expression of multiple cultural and strategic realities on both global and local levels, and the cognitive capacity to moderate and assimilate across this diversity. More specifically, global mindset is typified by three corresponding aspects: (1) an openness and attentiveness to multiple realms of action and meaning; (2) a complex representation and expression of cultural and strategic dynamics; and (3) a moderation and incorporation 
This is the version of the article accepted for publication in The Global Mindset. Advances in International Management published by Emerald doi:10.1016/S1571-5027(07)19002-1

Accepted version downloaded from SOAS Research Online: http://eprints.soas.ac.uk/32166

of ideals and actions oriented toward both global and local levels. These three factors generate a multidimensional continuum along which global mindset can be measured and appraised. Accordingly, individuals with the highest levels of global mindset are concurrently aware of and open to multiple realms of meaning and action, and are capable of bridging and synthesizing across these realms.

While we initially define global mindset at the individual level, as a cognitive construct, it can also be considered an attribute of groups and organizations and examined across multiple levels (Walsh, 1995; Schneider and Angelmar, 1993). In defining global mindset at the group and organizational levels, we take the position of methodological individualism that views system-level phenomenon as the result of orientations, actions, and interactions of individuals (Elster, 1989). Thus, global mindset can be conceptualized at the group or organizational level as a shared cognitive structure which emerges out of actions and interaction among individuals. As Walsh (1995:291) expresses it:

"...when a group of individuals is brought together, each with their own knowledge structure about a particular information environment, some kind of emergent collective knowledge structure is likely to exist. This group-level representation of an information environment would act just like an individual's knowledge structure. It too functions as a mental template that when imposed on an information environment gives it form and meaning, and in so doing serves as a cognitive foundation for action."

This emergent shared cognition represents an aggregation of individual cognitive structures which should take into account uneven power and influence of certain individuals within the group or organization (Walsh, 1995; Govindarajan and Gupta, 2001). However, we do not assume that the emergent cognition consists of nothing more than individuals' cognitions, orientations and actions taken in the aggregate (Coleman, 1990). Nor do we claim that the emergent cognition is intended or predicted by the individuals. Rather, we suggest that the actions and interactions among individuals are manifested in emergent shared cognition.

\section{Global Mindset and Information Processing}

The significance of global mindset hinges on the proposition that cognitive structures both represent and order an information domain and also extensively influence information processing. We 
This is the version of the article accepted for publication in The Global Mindset. Advances in International Management published by Emerald doi:10.1016/S1571-5027(07)19002-1

Accepted version downloaded from SOAS Research Online: http://eprints.soas.ac.uk/32166

investigate this connection by analyzing how global mindset shapes the cognitive capabilities of individuals and their decision-making patterns, thus applying considerable influence on managerial action and the firms' strategic capabilities.

Our framework is founded on the information processing theory. ${ }^{9}$ Analytically, we begin with a basic information processing model comprised of three stages: attention (or information acquisition), interpretation, and action (Daft and Weick, 1984). Generally, the information processing model is based on three underlying assumptions. First, individuals have limited information-processing capabilities and consequently focus on only certain aspects of the environment while ignoring others (Sproull, 1984). Second, environmental information undergoes an interpretation process that gives structure and meaning to the data (Daft and Weick, 1984). Third, these interpretations affect action (Daft and Weick, 1984; Dutton and Duncan, 1987; Kiesler and Sproull, 1982). Cognitive structures, including global mindset, influence the attention and interpretation processes, subsequently shaping future action. Furthermore, the impacts of individual cognitive structures are especially prominent in dynamic and complex environments that are distinguished by information overabundance, uncertainty, and ambiguity. Under such conditions, when the environment does not supply clear cognitive cues, attention and interpretation patterns have a tendency to echo individual predilections instead of environmental constraints (Abrahamson and Hambrick, 1997).

Utilizing the literature on cosmopolitanism and cognitive complexity, we can describe the impact that global mindset has on the "noticing and constructing meaning" processes (Kiesler and Sproull, 1982) in the context of rapid change, uncertainty, and complexity that exemplify the environment that managers face in most global organizations. At the attentional or information gathering stage, cognitive structures influence attention patterns by guiding attention toward certain facets of the environment, while "blocking" others; cognitive structures thus function as a lens through which individuals observe 
This is the version of the article accepted for publication in The Global Mindset. Advances in International Management published by Emerald doi:10.1016/S1571-5027(07)19002-1

Accepted version downloaded from SOAS Research Online: http://eprints.soas.ac.uk/32166

their environment. Global mindset consequently shapes information processing patterns by directing attention to various contrasting sources of information about both global and local environments.

Cosmopolitanism produces an open and tolerant position to the perception of information, thus allowing individuals to be open to, and to acquire information from, a number of sources regardless of their national or cultural origin. Simultaneously, cognitive complexity enables individuals to distinguish and keenly communicate more information elements and to incorporate them into more complex schemas. We therefore propose:

P1 Individuals who have a global mindset will pay attention to cultural and strategic dynamics on both global and local levels and will access multiple and diverse information sources upon which to base decisions.

The impact of cognitive structures goes beyond influencing attention and information acquisition to affect interpretative patterns, however. During the interpretation stage, cognitive structures have an effect on the process of "sense making" or how information is perceived, interpreted, assimilated, and understood (Daft and Weick, 1984). As described above, global mindset is characterized by openness and high levels of differentiation and integrative capacity. Information is therefore not only perceived, but also evaluated irrespective of its national or cultural origin. Likewise, individuals with high integrative abilities can amalgamate information from diverse and improbable sources and incorporate varied interpretative frameworks into the decision-making process. Lastly, reflexive interpretative processes have the potential to make possible the construction of a new and more complex understanding of the environment (Barr, Stimpert and Huff, 1992). Consequently, global mindset influences interpretative processes by encouraging the non-prejudicial and nonjudgmental perception and evaluation of information, incorporation of information from various sources, and deliberation on both the interpretative process itself and existing mental models. Individuals with a global mindset are more likely to deduce complex, innovative, and non-conventional explanations that do not simplify 
This is the version of the article accepted for publication in The Global Mindset. Advances in International Management published by Emerald doi:10.1016/S1571-5027(07)19002-1

Accepted version downloaded from SOAS Research Online: http://eprints.soas.ac.uk/32166

global realities, but rather present them in all their complexity, ambiguity, and indeterminacy. Hence, we propose that:

P2 Individuals who have a global mindset are likely to develop more complex and multifaceted conceptualizations of cultural and strategic dynamics on both global and local levels.

\section{Global Mindset and Effective Managerial Action}

As suggested earlier, the attention and interpretation processes associated with global mindset influence individuals' effectiveness in a global context. However, going beyond the confines of a single cultural or strategic view and considering multiple perspectives is insufficient for effective managerial action. Research in international management suggests that a set of core skills and competencies are required for effective managerial behavior in the global arena (Mendenhall and Osland, 2002; Von Glinow, 2001). For example, Bird and Osland (2004) develop a framework of global competencies where global mindset constitutes one of its building blocks. At the base of this pyramid-shaped framework, we find global knowledge and a set of four personality traits: integrity, humility, inquisitiveness, and hardiness. According to Bird and Osland (2004), the possession of adequate knowledge along with the prerequisite traits allows for the development of global mindset. However, these foundational competencies — knowledge, traits, and mindset— do not translate into effective managerial behavior unless the individual has the necessary interpersonal and system skills and abilities. At the interpersonal level, Bird and Osland (2004) specify the following two skills: mindful intercultural communication and the ability to build and create trust. At the system level, they denote the following skills: the ability to span boundaries, build community through change, and make ethical decisions. Bird and Osland (2004) also note that identifying a list of essential skills as opposed to making a comprehensive list of global leadership competencies is not an easy task. For the purpose of our discussion, however, we can conclude that while global mindset is a critical competency, effective 
This is the version of the article accepted for publication in The Global Mindset. Advances in International Management published by Emerald doi:10.1016/S1571-5027(07)19002-1

Accepted version downloaded from SOAS Research Online: http://eprints.soas.ac.uk/32166

managerial action in global context requires additional skills and abilities. Therefore, we suggest the following general proposition:

P3a Individuals who have a global mindset are likely to exhibit effective managerial action in a global context if they also possess the requisite set of skills and abilities.

We should note, however, that individuals who possess the requisite set of interpersonal and system skills and abilities are not likely to exhibit effective managerial action unless they also possess a global mindset. In this context, an interesting and yet unaddressed question is whether a person can develop the requisite set of skills and abilities without at least concurrently developing a global mindset. Drawing on Earley and Mosakowski (2004), we would argue that it is in fact difficult to develop the requisite set of interpersonal and system skills and abilities without a fairly high level of global mindset. These authors call this set of skills and abilities 'cultural intelligence' defined generally as when “...a person grasps what makes us human and at the same time what makes each of us different from one another" (Earley and Mosakowski, 2004:2) and is able to adjust behavior accordingly. Cultural intelligence has three sources: cognitive understanding of what makes a culture unique, driven by innate curiosity and a learning attitude; behavioral flexibility, the ability to "... receive and reciprocate gestures that are culturally characteristic;" and finally high self-efficacy, the confidence to believe that one can understand people from different cultures (Earley and Mosakowski, 2004:3). Cognitive understanding is necessary because it is difficult, given the complexity of the competing cultural factors that affect behavior (Osland and Bird, 2000), that a person can simply mimic the behavior of people in an unfamiliar culture and be appropriate unless s/he has understood the reasons for the behavior. Moreover, in-depth knowledge of a culture is necessary to know how to adjust behavior correctly for a myriad of unforeseen situations, and this knowledge. Earley and Erez (1997) argue that this begins with self-knowledge before proceeding to building knowledge about another culture. A person with high 
This is the version of the article accepted for publication in The Global Mindset. Advances in International Management published by Emerald doi:10.1016/S1571-5027(07)19002-1

Accepted version downloaded from SOAS Research Online: http://eprints.soas.ac.uk/32166

cosmopolitanism is more likely to exhibit the curiosity and openness that is necessary to accumulate this depth of knowledge about other cultures. In short, we would argue that a global mindset, especially cosmopolitanism, likely precedes the acquisition of the set of interpersonal and system skills and abilities that make effective managerial action possible in global settings, although we also recognize that the two are most likely self-reinforcing.

P3b The acquisition of the set of interpersonal and system skills and abilities necessary for effective managerial action in a global context is preceded by the acquisition of a significant level of global mindset, particularly cosmopolitanism.

\section{Global Mindset and Strategic Capabilities of Firms}

The "noticing and constructing meaning" processes linked to global mindset may have important implications for the strategic capabilities of the firm. Whereas strategic behavior is influenced by a large number of factors, both the managerial cognition and the upper echelon perspectives imply that information processing capabilities of employees, especially those in senior positions, have a very strong effect on strategic response (e.g., Hambrick and Mason, 1984; Stubbart, 1989; Barkema and Vermeulen, 1998; Egelhoff, 1991; Finkelstein and Hambrick, 1996; Nystrom and Starbuck, 1984; Ford, 1985; Thomas, Clark, and Gioia, 1993). What is more, these capabilities are particularly significant under conditions of complexity, uncertainty, and rapid change, when strategic response entails interpreting and "enacting" the business environment (Daft and Weick, 1984; Smircich and Stubbart, 1985; Carpenter and Fredrickson, 2001). Senior managers thus interpret issues applicable to strategic decision-making, and will typically have the status required to execute choices resulting from those interpretations (Hambrick and Mason, 1984). Here we suggest that because senior executives who possess a global mindset are externally focused rather than internally focused, they are more likely to be exposed to diverse sources of information and develop insights regarding environmental dynamics, threats and 
This is the version of the article accepted for publication in The Global Mindset. Advances in International Management published by Emerald doi:10.1016/S1571-5027(07)19002-1

Accepted version downloaded from SOAS Research Online: http://eprints.soas.ac.uk/32166

opportunities as well as changes and trends. This managerial focus is likely to result in superior and innovative strategies (D'Aveni and MacMillan, 1990; Egelhoff, 1993; Geletkanycz and Hambrick, 1997). If, in addition to global mindset, senior executives also possess enough influence within their firm, they can enact these superior strategies (Athanassiou and Nigh, 2002). Thus, we propose that:

P4 Senior executives who possess a global mindset and who are sufficiently influential within their firm are more likely to formulate and enact superior global strategies.

At the same time, some recent evidence suggests that global mindset may not always translate into superior performance and effectiveness. For example, Bouquet (2005) finds a curvilinear relationship between TMT global mindset and firm performance. Beyond intermediate levels of global mindset, MNCs experience diminishing returns, after which negative returns set in. Roth (1995) also reports a negative relationship between CEO's expatriate experience and performance in the case of companies with low levels of international interdependence. This evidence suggests that the relationship between global mindset and organizational effectiveness may be contingent on organizational strategy and environmental factors. Thus, we propose that the impact of global mindset on organizational effectiveness is most likely mediated by strategy implementation capabilities and moderated by environmental and firm characteristics.

As we suggested earlier, for firms competing globally, global mindset results in superior strategies. Thus, the competitive advantage of firms whose senior executives possess a global mindset is often largely based on superior global strategies as opposed to superior strategy implementation capabilities (Egelhoff, 1993). While at times competing through superior strategy may be sufficient, it is often impossible to consistently stay a ahead of the competition if competitors possess superior strategy implementation capabilities (Egelhoff, 1993). Moreover, the effect of superior global strategies may short-lived unless significant entry barriers are erected. Thus, in absence of significant global 
This is the version of the article accepted for publication in The Global Mindset. Advances in International Management published by Emerald doi:10.1016/S1571-5027(07)19002-1

Accepted version downloaded from SOAS Research Online: http://eprints.soas.ac.uk/32166

implementation capabilities and adequate support structures and processes, global mindset may not translate into long-term competitive advantage. Therefore, we propose that the impact of global mindset on effectiveness is at least partially mediated by global strategic implementation capabilities. Thus, we propose that:

P5 Global strategic implementation capabilities will partially mediate the relationship between global mindset and organizational effectiveness.

Obviously, strategy implementation capabilities in MNCs is one of the most compelling issues outstanding in the field of international management (Kim and Mauborgne, 1996). Developing implementation capabilities may involve a host of initiatives (Bartlett and Ghoshal, 1989; Prahalad and Doz, 1987) and repeated cycles of aligning and fine-tuning. In this context, we would like to point to two, often neglected, mechanisms that can enhance the impact of global mindset on organizational effectiveness. First, we suggest that MNCs need to develop a shared understanding of what it means to be a global company (Levy, Boyacigiller, Taylor and Beechler, 2002). We argue that the ways in which the practice of globalization is debated, interpreted, defined, and shared dramatically affects various aspects of organizational life, including global strategy implementation. Often, senior managers possess a global mindset and have broad and deep conceptions of globalization realities and dynamics. However, companies as a whole frequently cannot effectively translate these complex individual understandings into organizational policies and actions. Thus, global mindset does not translate into a complex company-wide interpretation and implementation of global strategy. Thus, developing a shared understanding of the practice of globalization through an ongoing constructive debate can facilitate translating global mindset into a company-wide platform and assist in global strategy implementation (Levy et al., 2002). 
This is the version of the article accepted for publication in The Global Mindset. Advances in International Management published by Emerald doi:10.1016/S1571-5027(07)19002-1

Accepted version downloaded from SOAS Research Online: http://eprints.soas.ac.uk/32166

Second, we suggest that MNCs need to develop flexible structures and processes that span organizational boundaries in order to disseminate global mindset throughout the corporation (Bartlett and Ghoshal, 1989; Bartlett and Ghoshal, 2000; Ashkenas et al., 1995). As we suggested above, global mindset often does not travel well across geographies, functions, and hierarchies within the corporation. Thus, establishing boundary spanning processes and practices such as global responsibility designations, global team participation, ad hoc project groups, networks, and shared task groups (Adler and Bartholomew, 1992b; Ashkenas et al., 1995; Bartlett and Ghoshal, 1989; Nohria and Ghoshal, 1997; Pucik, Tichy and Barnett, 1992) can influence the promulgation of global mindset, thus unifying employees around a common understanding and set of objectives. This shared understanding, in turn, can facilitate global strategy implementation by promoting communication and cooperation across organizational boundaries.

In addition, we suggest that the effect of global mindset on effectiveness is most likely moderated by environmental and firm characteristics. Thus, we argue that an optimal fit between global mindset and environmental and firm characteristics can positively affect organizational effectiveness rather than global mindset by itself. Specifically, we focus one two key considerations, namely, the level of environmental dynamism and complexity and the firm's international strategy.

Senior executives who operate in an environment characterized by rapid changes, dynamism, and complexity must have a global mindset in order to understand and respond to their environment. Under such conditions, global mindset is more likely to have a positive influence on firm's effectiveness. On the other hand, it is quite possible that when executives operate in a relatively stable environment, global mindset becomes irrelevant or even a liability because it imposes unnecessary complexity where simplicity is called for. Therefore, we propose that for global mindset to have a positive impact on 
This is the version of the article accepted for publication in The Global Mindset. Advances in International Management published by Emerald doi:10.1016/S1571-5027(07)19002-1

Accepted version downloaded from SOAS Research Online: http://eprints.soas.ac.uk/32166

effectiveness, there should be a fit between environmental conditions and the level of global mindset of senior executives:

P6 A fit between environmental conditions and managerial global mindset will be positively associated with organizational effectiveness.

Similarly, a firm's international strategy is also likely to affect the relationship between global mindset and effectiveness. High levels of internationalization place high levels of informationprocessing demands on senior executives and likely to require significant information processing capabilities or a global mindset. On the other hand, Roth (1995) finds that strong CEO international experience negatively affects performance when international interdependence is low. Thus, it is quite possible that global mindset has a positive impact on organizational effectiveness in the case of high levels of internationalization and is irrelevant or even damaging in the case of low levels of internationalization. This suggests that for global mindset to have a positive impact on effectiveness, there should be a fit between international strategy of the firm and the level of global mindset of its senior executives:

P7 A fit between international strategy of the firm and managerial global mindset will be positively associated with organizational effectiveness.

It should be noted, however, that global mindset entails high levels of information processing demands which could overwhelm decision makers, slowing down decision making to unacceptable levels, Thus, it is possible that even when higher levels of global mindset among key decision makers is required, global mindset will have a positive impact on a firm's effectiveness only when it is accompanied by support structures and processes within the firm such as modular networks, communities of practice, distributed management and centers of excellence (Begley and Boyd, 2003). 
This is the version of the article accepted for publication in The Global Mindset. Advances in International Management published by Emerald doi:10.1016/S1571-5027(07)19002-1

Accepted version downloaded from SOAS Research Online: http://eprints.soas.ac.uk/32166

\section{Summary and Implications}

The capabilities linked to global mindset are crucial elements in contemporary MNCs, considerably influencing the global competitiveness of firms. Researchers, however, are faced with the challenge of explaining the complex construct of global mindset and further identifying its antecedents and outcomes. To assist in advancing the field we have suggested a framework that details the core properties of global mindset and creates a link between global mindset and global competitiveness of firms. In conclusion, we now discuss the implications of our integrative framework and suggest directions for future research.

\section{Implications of the Integrative Framework}

As our review and analysis of the literature imply, there are still important unanswered questions concerning global mindset. The integrative framework we propose presents a parsimonious conceptualization of global mindset and focuses on the following major questions:

1. What are the core properties of global mindset?

2. At what level(s) of analysis should global mindset be studied?

3. Is global mindset a unidimensional or a multidimensional construct?

4. How should global mindset be operationalized and measured at each level of analysis?

5. What are the possible links between global mindset and effective global management?

To begin, we define global mindset as a highly complex individual-level cognitive structure characterized by openness, differentiated articulation of cultural and strategic dynamics on both local and global scales, and integration across these multiple domains. We therefore define the core properties of global mindset in cognitive terms in place of offering an exhaustive list of attitudes, dispositions, and skills. Simultaneously, we propose that global mindset, embodying the cognitive basis 
This is the version of the article accepted for publication in The Global Mindset. Advances in International Management published by Emerald doi:10.1016/S1571-5027(07)19002-1

Accepted version downloaded from SOAS Research Online: http://eprints.soas.ac.uk/32166

of effective global management, should be connected with competencies, skills, and behaviors, so as to develop a more complete model of effective management in the global context.

Second, we first delineate global mindset at the individual level of analysis. We then broaden this classification to describe global mindset at the group- and organization-levels of analysis. Consequently, we propose that at the group-and organizational-level, global mindset should be considered a shared cognitive structure that can be analyzed across multiple levels (Walsh, 1995; Schneider and Angelmar, 1993). One benefit of conceptualizing global mindset as a cognitive construct is its robustness across levels. Additionally, a cognitive approach assists in strengthening the causal determinants of global mindset at different levels of analysis, and in elucidating the relationships between global mindset across levels.

Third, our approach clearly demonstrates that global mindset is a multidimensional construct, integrating both cultural and strategic dimensions, as well as local and global levels. These dimensions offer an introductory map of the pertinent content domain of global mindset. From a cognitive perspective, however, content is only one aspect of cognitive structures. Conceptually, cognitive structures can be evaluated in terms of their content and/or structure (Walsh, 1995). Hence, besides outlining the relevant content domain of global mindset, our definition of global mindset additionally describes its structural properties by proposing that it is a complex cognitive structure distinguished by high differentiation, articulation, and integration.

Fourth, by defining global mindset using a cognitive framework and by stipulating both its structural and content dimensions, we offer an approach that is conducive to operationalization. It is beyond the scope of this article to provide a systematic review of methods to analyze cognition. However, the managerial cognition literature offers several approaches to measuring both the content and structure of cognitive structures (see Walsh, 1995 for detailed review; see also Huff, 1990; Barr, 
This is the version of the article accepted for publication in The Global Mindset. Advances in International Management published by Emerald doi:10.1016/S1571-5027(07)19002-1

Accepted version downloaded from SOAS Research Online: http://eprints.soas.ac.uk/32166

Stimpert, and Huff, 1992; Calori, Johnson, and Sarnin, 1994; Lant, Milliken, and Batra, 1992). Calori et al. (1994) for instance, used the cognitive mapping technique to assess the complexity of managerial mindset, while Barr et al. (1992) employed textual analysis of organizational documents to measure the mental models of executives.

As a final point, we investigate the information processing consequences of global mindset, thus suggesting a clear theory-based link between global mindset and effective global management. We propose that global mindset has a powerful impact on information processing patterns that may translate into superior managerial capabilities for firms operating in the global arena. Consequently, grounding global mindset in the cognitive and information processing literature can facilitate a more rigorous examination of the frequently stated but rarely tested assumption that a global mindset is required for the successful management of global firms (Bartlett and Ghoshal, 1992; Ohmae, 1989; Doz and Prahalad, 1991). However, we qualify this proposition and suggest that global mindset in-and-of-itself may be insufficient. Thus, in addition to global mindset a set of core skills and competencies are required for effective managerial behavior in the global arena as well as supporting organization structures and processes. Moreover, we also suggest that the effect of global mindset on effectiveness is most likely moderated by environmental conditions and the firm's international strategy. Therefore, for global mindset to have a positive impact on effectiveness, there should be a fit between environmental and strategic circumstances and the level of global mindset of senior executives.

As the literature reviewed in this article demonstrates, scholars from various disciplines have endeavored to define global mindset. This has created a multitude of definitions, which is an indication that global mindset is a relatively young field. In addition, the proliferation of dimensions often used to describe global mindset makes it complicated to assess and test propositions regarding global mindset. We offer an approach that is easier to both understand and operationalize in future research efforts, by 
This is the version of the article accepted for publication in The Global Mindset. Advances in International Management published by Emerald doi:10.1016/S1571-5027(07)19002-1

Accepted version downloaded from SOAS Research Online: http://eprints.soas.ac.uk/32166

defining global mindset using a cognitive framework. We also underscore managerial cognitive capabilities in MNCs in the hope of producing a "cognitive revolution" in international management research. In our appeal for a renewed emphasis on cognition, we follow the lead of Doz and Prahalad (1991) who maintained that the newly emerging MNC necessitates a paradigmatic shift to a model where the mindsets or cognitive orientations of managers comprise the basic unit of analysis. 
This is the version of the article accepted for publication in The Global Mindset. Advances in International Management published by Emerald doi:10.1016/S1571-5027(07)19002-1

Accepted version downloaded from SOAS Research Online: http://eprints.soas.ac.uk/32166

\section{Notes}

${ }^{1}$ This paper draws heavily on our comprehensive review of the literature on global mindset, "What We Talk about When we Talk about "Global Mindset": Managerial Cognition in Multinational Corporations," Journal of International Business Studies (Levy, Beechler, Taylor and Boyacigiller, forthcoming). The paper contains material based upon work supported by the National Science Foundation under Grant No. 0080703. Any opinions, findings, and conclusions or recommendations expressed in this material are those of the authors and do not necessarily reflect the views of the National Science Foundation. The authors would also like to thank Columbia University, Portland State University, Sabanci University, San Jose State University, and the International Consortium for Executive Development Research for their support of this research. The authors also gratefully acknowledge the research assistance of Elif Cicekli and Pinar Imer, and the editorial assistance of Hester Yorgey.

${ }^{2}$ Although outside the scope of this paper, a similar theme can be found in the literature on global leadership (e.g., McCall and Hollenbeck, 2002).

${ }^{3}$ Merton (1957) initially conceptualized cosmopolitans as individuals who are oriented toward the outside world and locals as those who are narrowly concerned with the affairs of the community to the exclusion of world affairs. Extending this concept to university faculty, Gouldner (1957:290) characterized cosmopolitans as "those lower on loyalty to the employing organization, higher in commitment to their specialized role skills, and more likely to use outer reference group orientation" (Gouldner 1957:290). While the cosmopolitan-local distinction was parsimonious, subsequent research (e.g., Gouldner, 1958; Flango and Brumbaugh 1974; Glaser 1963; Goldberg, Baker, and Rubenstein 1965; Goldberg 1976) found the construct to be more complex and multidimensional. For example, Gouldner (1958) divided cosmopolitans into two groups: outsiders and empire builders. Locals were split into four groups: dedicated, true bureaucrats, homeguards, and elders. Goldberg et al. (1965) expanded the cosmopolitan-local classification system to include four categories. In addition to the cosmopolitan and local categories, a third category, termed "complex," described those employees who are simultaneously loyal to both their employing organization and profession. The fourth category, termed "indifferent" described those employees who were loyal to neither.

${ }^{4}$ Within the past five years, a host of initiatives and publications concerning cosmopolitanism have appeared (see Hollinger, 2002 for a review of these developments). While we draw on this literature, a comprehensive discussion of the concept of cosmopolitanism is beyond the scope of this brief overview.

${ }^{5}$ It should be noted that while cosmopolitans are celebrated by some as the new "cultural heroes" of the global economy, they have frequently come under attack as they are viewed as privileged (Clifford, 1988; Robbins, 1992; Vertovec and Cohen, 2002). While considerable debate has focused on the value-laden aspects of cosmopolitanism, we believe that it is not necessary to overlay the construct with assumptions of superiority (Robbins, 1992).

${ }^{6}$ The most explicit example of a multidimensional measure is used by Murtha et al. who draw on the integrationresponsiveness framework (Prahalad and Doz, 1987). They measure global mindset in terms of managers' expectations regarding integration, responsiveness, and coordination. Similarly, Arora (2004) uses a self-report instrument that reflects two drivers of global value (local competencies and global coordination) suggested by Govindarajan and Gupta (2001).

${ }^{7}$ According to Rousseau (1985:8) "isomorphism exists when the same functional relationship can be used to represent constructs at more than one level...isomorphism implies that constructs mean the same thing across levels..." Partial identity implies that constructs, although similar, "behave" somewhat differently across levels. In addition, the same constructs used at different levels may be only weakly related.

${ }^{8}$ Arora et al. (2004), for example, established the construct validity of their global mindset measure by testing the relationships between global mindset and a set of individual background characteristics (training in international management, foreign country living experience and job experience, family member of foreign origin), often considered to be antecedents of global mindset. They found that global mindset was significantly positively related to these characteristics. These theoretically predicted relationships tentatively support Arora's et al. (2004) global mindset measure.

${ }^{9}$ While information processing theory has been applied at the individual (e.g., Hult and Ferrell, 1997; Leonard, Scholl, and Kowalski, 1999; Wang and Chan, 1995), top management team (e.g., Sweet, Roome, and Sweet, 2003), and organizational levels of analysis (e.g., Wang, 2003; Egelhoff, 1991), consistent with our approach to global mindset as an individual-level construct, our primary focus in this discussion is at the individual level. At the same time, there is an obvious and important overlap between the levels of analysis, as the more macro strategy literature views the top management team of MNCs as the location where a large portion of the strategic information processing capacity of the organization lies (Egelhoff, 1991:197). 
This is the version of the article accepted for publication in The Global Mindset. Advances in International Management published by Emerald doi:10.1016/S1571-5027(07)19002-1

Accepted version downloaded from SOAS Research Online: http://eprints.soas.ac.uk/32166

\section{References}

Abrahamson, E. and Hambrick, D. C. (1997). 'Attentional Homogeneity in Industries: The Effect of Discretion', Journal of Organizational Behavior, 18(Special Issue): 513-532.

Adler, N. J. and Bartholomew, S. (1992a). 'Globalization and Human Resource Management'. In Rugman, A. M. and Verbeke, A. (eds) Research in Global Strategic Management: Corporate Response to Change,. Greenwich, CT: JAI Press, pp. 179-201.

Adler, N. J. and Bartholomew, S. (1992b). 'Managing Globally Competent People', Academy of Management Executive, 6(3): 52-62.

Aharoni, Y. (1966). The Foreign Investment Decision Process Boston: Division of Research, Graduate School of Business, Harvard University.

Archibugi, D. (ed) (2003). Debating Cosmopolitics. London: Verso.

Arora, A., Jaju, A., Kefalas, A. G. and Perenich, T. (2004). 'An Exploratory Analysis of Global Managerial Mindsets: A Case of U.S. Textile and Apparel Industry', Journal of International Management, 10(3): 393-411.

Ashkenas, R., Ulrich, D., Jick, T. and Kerr, S. (1995). The Boundaryless Organization: Breaking the Chains of Organizational Structure San Francisco: Jossey-Bass.

Athanassiou, N. and Nigh, D. (2002). 'The Impact of the Top Management Team's International Business Experience on the Firm's Internationalization: Social Networks at Work', Management International Review, 42(2): 157-181.

Barkema, H. G. and Vermeulen, F. (1998). 'International Expansion through Start-Up or Acquisition: A Learning Perspective', Academy of Management Journal, 41(1): 7-26.

Barr, P. S., J., Stimpert, J. L. and Huff, A. S. (1992). 'Cognitive Change, Strategic Action, and Organizational Renewal', Strategic Management Journal, 13: 15-36.

Bartlett, C. A. and Ghoshal, S. (1989). Managing Across Boarders: The Transnational Solution Boston: Harvard Business School Press.

Bartlett, C. A. and Ghoshal, S. (1990). 'Matrix Management: Not a Structure, a Frame of Mind', Harvard Business Review, 68(4): 138-145.

Bartlett, C. A. and Ghoshal, S. (1992). 'What is a Global Manager?' Harvard Business Review, 70(5): 124-32.

Bartlett, C. A. and Ghoshal, S. (2000). Transnational Management: Text, Cases and Readings in Cross-Border Management (3rd Edition). Boston: Irwin/McGraw Hill. 
This is the version of the article accepted for publication in The Global Mindset. Advances in International Management published by Emerald doi:10.1016/S1571-5027(07)19002-1

Accepted version downloaded from SOAS Research Online: http://eprints.soas.ac.uk/32166

Bartunek, J. M., Gordon, J. R. and Weathersby, R. P. (1983). 'Developing 'Complicated' Understanding in Administrators', Academy of Management Review, 8(2): 273-284.

Beck, U. (2000). 'The Cosmopolitan Perspective: Sociology and the Second Age of Modernity', British Journal of Sociology, 51(7): 79-105.

Beechler, S., Levy, O., Taylor, S. and Boyacigiller, N. (2004). 'Does it Really Matter if Japanese MNCs Think Globally?' In Bird, A. and Roehl, T. (eds) Japanese Firms in Transition: Responding to the Globalization Challenge. Greenwich, CT: JAI Press, pp. 265-292.

Begley, T. M. and Boyd, D. P. (2003). 'The Need for a Corporate Global Mind-Set', MIT Sloan Management Review, 44(2): 25-32.

Bieri, J. (1955). 'Cognitive Complexity-Simplicity and Predictive Behavior', Journal of Abnormal and Social Psychology, 51(261-68.

Bird, A. and Osland, J. (2004). 'Global Competencies: An Introduction'. In Lane, H., Mendenhall, M., Maznevski, M. and McNett, J. (eds) Handbook of Global Management: A Guide to Managing Complexity. Oxford: Blackwell.

Bouquet, C., A. (2005). Building Global Mindsets: An Attention-Based Perspective New York: Palgrave Macmillan.

Breckenridge, C. A., Pollock, S., Bhabha, H. K. and Chakrabarty, D. (eds) (2000). Cosmopolitanism. London: Duke University Press.

Caligiuri, P., Lazarova, M. and Zehetbauer, S. (2004). 'Top Managers' National Diversity and Boundary Spanning: Attitudinal Indicators of a Firm's Internationalization', The Journal of Management Development, 23(9): 848-859.

Calori, R., Johnson, G. and Sarnin, P. (1994). 'CEO's Cognitive Maps and the Scope of the Organization', Strategic Management Journal, 15: 437-457.

Caproni, P. J., Lenway, S. A. and Murtha, T. P. (1992). 'Multinational Mind Sets: Sense Making Capabilities as Strategic Resources in Multinational firm', Division of Research, School of Business Administration, The University Of Michigan.

Carmines, E. G. and Zeller, R. A. (1979). Reliability and Validity Assessment Newbury Park, CA: Sage Publications.

Carpenter, M. A. and Fredrickson, J. W. (2001). 'Top Management Teams, Global Strategic Posture, and the Moderating Role of Uncertainty', Academy of Management Journal, 44(3): 533-545.

Carpenter, M. A., Sanders, W. G. and Gregersen, H. B. (2001). 'Bundling Human Capital with Orgainzational Context: The Impact of International Assignment Experience on Multinational Firm Performance and CEO Pay', Academy of Management Journal, 44(3): 493-511. 
This is the version of the article accepted for publication in The Global Mindset. Advances in International Management published by Emerald doi:10.1016/S1571-5027(07)19002-1

Accepted version downloaded from SOAS Research Online: http://eprints.soas.ac.uk/32166

Chakravarthy, A. and Perlmutter, H. (1985). 'Strategic Planning for a Global Economy', Columbia Journal of World Business, Summer: 3-10.

Chang, C. K. and McDaniel, E. D. (1995). 'Information Search Strategies in Loosely Structured Settings', Journal of Educational Computing Research, 12(1): 95-107.

Clifford, J. (1988). 'On Orientalism'. The Predicament of Culture. Cambridge, MA: Harvard University Press, pp. 255-276.

Coleman, J. S. (1990). Foundations of Social Theory Cambridge, Mass: Belknap Press of Harvard University Press.

Daft, R. L. and Weick, K. E. (1984). 'Toward a Model of Organizations as Interpretation Systems', Academy of Management Review, 9(2): 284-295.

Daily, C. M., Certo, S. T. and Dalton, D. R. (2000). 'International Experience in the Executive Suite: The Path to Prosperity?' Strategic Management Journal, 21(4): 515-523.

D'Aveni, R. A. and MacMillan, I. C. (1990). 'Crisis and the Content of Managerial Communications: A Study of the Focus of Top Managers in Surviving and Failing Firms', ASQ, 35: 634-657.

Dollinger, M. J. (1984). 'Environmental Boundary Spanning and Information Processing Effects on Organizational Performance', Academy of Management Journal, 27(2): 351-68.

Doz, Y., Santos, J. and Williamson, P. (2001). From Global to Metanational: How Companies Win in the Knowledge Economy Boston: Harvard Business School Press.

Doz, Y. L. and Prahalad, C. K. (1991). 'Managing DMNCs: A Search for a New Paradigm', Strategic Management Journal, 12: 145-164.

Duhaime, I. M. and Schwenk, C. R. (1985). 'Conjectures on Cognitive Simplification in Acquisition and Divestment Decision Making', Academy of Management Review, 10(2): 287-295.

Dutton, J. E. and Duncan, R. B. (1987). 'The Influence of the Strategic Planning Process on Strategic Chance', Strategic Management Journal, 8: 103-116.

Earley, P. C. and Erez., M. (1997). The Transplanted Executive New York and Oxford: Oxford University Press.

Earley, P. C. and Mosakowski, E. (2004). 'Cultural Intelligence', Harvard Business Review, $82(10)$.

Egelhoff, W. G. (1991). 'Information-Processing Theory and the Multinational Enterprise', Journal of International Business Studies, 22(3): 341-368. 
This is the version of the article accepted for publication in The Global Mindset. Advances in International Management published by Emerald doi:10.1016/S1571-5027(07)19002-1

Accepted version downloaded from SOAS Research Online: http://eprints.soas.ac.uk/32166

Egelhoff, W. G. (1993). 'Great Strategy or Great Strategy Implementation - Two Ways of Competing in Global Markets', Sloan Management Review, 34(2): 37-50.

Elster, J. (1989). Nuts and Bolts for the Social Sciences Cambridge: Cambridge University Press.

Estienne, M. (1997). 'The Art of Cross-Cultural Management: "An Alternative Approach to Training and Development"', Journal of European Industrial Training, 21(1): 14-18.

Evans, P. and Doz., Y. (1992). 'Dualities: A Paradigm for Human Resource and Organizational Development in Complex Multinationals'. In Pucik, V., Tichy, N. and Barnett, C. (eds) Globalizing Management: Creating and Leading the Competitive Organization. New York: John Wiley and Sons.

Evans, P., Pucik, V. and Barsoux, J.-L. (2002). The Global Challenge: Frameworks for International Human Resource Management Boston, MA: McGraw-Hill Irwin.

Finkelstein, S. and Hambrick, D. C. (1996). Strategic Leadership: Top Executives and Their Effects on Organizations St. Paul, MN: West Publishing Company.

Flango, V. E. and Brumbaugh, R. B. (1974). 'The Dimensionality of the Cosmopolitan-Local Construct', Administrative Science Quarterly, 19: 198-210.

Ford, D. (1985). 'The Effects of Causal Attributions on Decision Makers' Responses to Performance Downturns', Academy of Management Review, 10: 770-786.

Geletkanycz, M. A. and Hambrick, D. C. (1997). 'The External Ties of Top Executives: Implications for Strategic Choice and Performance', ASQ, 42: 654-681.

Ginsberg, A. (1990). 'Connecting Diversification to Performance: A Sociocognitive Approach', Academy of Management Review, 15(3): 514-535.

Glaser, B. G. (1963). 'The Local-Cosmopolitan Scientist', American Journal of Sociology, 69: 249-259.

Goldberg, A. I. (1976). 'The Relevance of Cosmopolitan/Local Orientations to Professional Values and Behavior', Sociology of Work and Occupation, 3(3): 331-356.

Goldberg, L. C., Baker, F. and Rubenstein, A. H. (1965). 'Local-Cosmopolitan: Unidimensional or Multidimensional?' American Journal of Sociology, 70: 704-710.

Gouldner, A. W. (1957). 'Cosmopolitans and Locals: Toward an Analysis of Latent Social Roles-I', Administrative Science Quarterly, 2: 281-306.

Gouldner, A. W. (1958). 'Cosmopolitans and Locals: Toward an Analysis of Latent Social Roles-II', Administrative Science Quarterly, 2: 444-480.

Govindarajan, V. and Gupta, A. (1998). 'Success is All in the Mindset', Financial Times, February 27. 
This is the version of the article accepted for publication in The Global Mindset. Advances in International Management published by Emerald doi:10.1016/S1571-5027(07)19002-1

Accepted version downloaded from SOAS Research Online: http://eprints.soas.ac.uk/32166

Govindarajan, V. and Gupta, A. K. (2001). The Quest for Global Dominance: Transforming Global Presence into Global competitive Advantage San Francisco: Jossey-Bass.

Gregersen, H. B., Morrison, A. J. and Black, J. S. (1998). 'Developing Leaders for the Global Frontier', Sloan Management Review, 40(1): 21-39.

Gupta, A. K. and Govindarajan, V. (2002). 'Cultivating a Global Mindset', The Academy of Management Executive, 16(1): 116-126.

Hambrick, D. C. and Mason, P. (1984). 'Upper Echelons: The Organization as a Reflection of its Top Managers', Academy of Management Review, 9: 193-206.

Hannerz, U. (1996). 'Cosmopolitans and Locals in World Culture'. In Hannerz, U. (ed) Transnational Connections: Culture, People, Places. London: Routlege, pp. 102-111.

Harveston, P. D., Kedia, B. L. and Davis, P. S. (2000). 'Internationalization of Born Global and Gradual Globalizing Firms: The Impact of the Manager', Advances in Competitiveness Research, 8(1): 92-99.

Harvey, D. (2000). 'Cosmopolitanism and the Banality of Geographical Evils', Public Culture, 12(2): 529-564.

Harvey, O. J., Hunt, D. and Schroder, H. M. (1961). Conceptual Systems and Personality Organization New York: Wiley.

Heenan, D. and Perlmutter, H. (1979). Multinational Organizational Development: A Social Architecture Perspective Reading, MA: Addison-Wesley.

Herrmann, P. and Datta, D. K. (2002). 'CEO Successor Characteristics and the Choice of Foreign Market Entry Mode: An Empirical Study', Journal of International Business Studies, 33(3): 551-569.

Hollinger, D. A. (2002). 'Not Universalists, Not Pluralists: The New Cosmopolitans Find Their Way'. In Vertovec, S. and Cohen, R. (eds) Conceiving Cosmopolitanism: Theory, Context, and Practice. Oxford: Oxford University Press.

Huff, A. S. (1990). 'Mapping Strategic Thought'. In Huff, A. S. (ed) Mapping Strategic Thought. New York: John Wiley and Sons, pp. 11-49.

Hult, G. T. M. and Ferrell, O. C. (1997). 'A Global Learning Organization Structure and Market Information Processing', Journal of Business Research, 40(2): 155-166.

Jeannet, J.-P. (2000). Managing with a Global Mindset London: Financial Times/Prentice Hall.

Kanter, R. M. (1995). World Class: Thriving Locally in the Global Economy New York: Simon and Schuster. 
This is the version of the article accepted for publication in The Global Mindset. Advances in International Management published by Emerald doi:10.1016/S1571-5027(07)19002-1

Accepted version downloaded from SOAS Research Online: http://eprints.soas.ac.uk/32166

Karlins, M. and Lamm, H. (1967). 'Information Search as a Function of Conceptual Structure in a Complex Problem-Solving Task', Journal of Personality and Social Psychology, 5(4): 456-459.

Kedia, B. L. and Mukherji, A. (1999). 'Global Managers: Developing a Mindset for Global Competitiveness', Journal of World Business, 34(3): 230-251.

Kefalas, A. (1998). 'Think Globally, Act Locally', Thunderbird International Business Review, 40(6): 547-562.

Kefalas, A. G. and Neuland, E. W. (1997). 'Global Mindsets: An Exploratory Study', Annual Conference of the Academy of International Business, Moneterrey, Mexico.

Kefalas, A. G. and Weatherly, E. W. (1998). 'Global Mindsets among College Students in the United States and Elsewhere: Are We Growing a Globally Minded Workforce?'

Kiesler, S. and Sproull, L. (1982). 'Managerial Response to Changing Environments: Perspectives on Problem Sensing from Social Cognition', Administrative Science Quarterly, 27: 548-570.

Kim, W. C. and Mauborgne, R. A. (1996). 'Procedural Justice, and Managers' In-Role and ExtraRole Behavior: The Case of the Multinational', Management Science, 42: 499-515.

Kindleberger, C. P. (1969). American Business Abroad: Six Lectures on Direct Investment New Haven, CT: Yale University Press.

Kobrin, S. J. (1994). 'Is there a Relationship between a Geocentric Mind-Set and Multinational Strategy?' Journal of International Business Studies, 25(3): 493-511.

Lant, K. T., Milliken, F. J. and Batra, B. (1992). 'The Role of Managerial Learning and Interpretation in Strategic Persistence and Reorientation: An Empirical Exploration', Strategic Management Journal, 13: 585-608.

Leonard, N. H., Scholl, R. W. and Kowalski, K. B. (1999). 'Information Processing Style and Decision Making', Journal of Organizational Behavior, 20(3): 407-420.

Lepsinger, R., Mullen, T. P., Stumpf, S. A. and Wall, S. J. (1989). Large Scale Management Simulations: A Training Technology for Assessing and Developing Strategic Management Skills. Advances in Management Development New York: Praeger.

Levy, O. (2005). 'The Influence of Top Management Team Attention Patterns on Global Strategic Posture of Firms', Journal of Organizational Behavior, 26: 797-819.

Levy, O., Beechler, S., Taylor, S. and Boyacigiller, N. (forthcoming). 'What We Talk About When We Talk About "Global Mindset": Managerial Cognition in Multinational Corporations', Journal of International Business Studies. 
This is the version of the article accepted for publication in The Global Mindset. Advances in International Management published by Emerald doi:10.1016/S1571-5027(07)19002-1

Accepted version downloaded from SOAS Research Online: http://eprints.soas.ac.uk/32166

Levy, O., Boyacigiller, N., Taylor, S. and Beechler, S. (2002). 'Managers' Voices: Globalization Discourse in Multinational Corporations', The Annual Meeting of the Western Academy of Management, Santa Fe, New Mexico.

Maznevski, M. L. and Lane, H. W. (2004). 'Shaping the Global Mindset: Designing Educational Experiences for Effective Global Thinking and Action'. In Boyacigiller, N., Goodman, R. M. and Phillips, M. (eds) Crossing Cultures: Insights from Master Teachers. London: Routledge, pp. 171-184.

McCall, M. and Hollenbeck, G. (2002). Development Experiences of Global Executives Cambridge, Mass.: Harvard Business School.

Mendenhall, M. and Osland, J. S. (2002). 'An Overview of the Extant Global Leadership Research`, Symposium Presentation, Academy of International Business, Puerto Rico.

Merron, K., Fisher, D. and Torbert, W. R. (1987). 'Meaning Making and Management Action', Group and Organizational Studies, 12: 274-286.

Merton, R. K. (1957). 'Patterns of Influence: Local and Cosmopolitan Influentials'. In Merton, R. K. (ed) Social Theory and Social Structure. Glencoe, IL: Free Press.

Miller, D. (1993). 'The Architecture of Simplicity', Academy of Management Review, 18(1): 116-138.

Murtha, T. P., Lenway, S. A. and Bagozzi, R. P. (1998). 'Global Mind-Sets and Cognitive Shift in a Complex Multinational Corporation', Strategic Management Journal, 19(2): 97-114.

Neff, P. J. (1995). 'Cross-Cultural Research Teams in a Global Enterprise', Research Technology Management, 38(3): 15-19.

Nohria, N. and Ghoshal, S. (1997). The Differentiated Network: Organizing Multinational Corporations for Value Creation San Francisco: Jossey-Bass Publishers.

Nummela, N., Saarenketo, S. and Puumalainen, K. (2004). 'A Global Mindset - A Prerequisite for Successful Internationalization?' Canadian Journal of Administrative Sciences, 21(1): $51-64$.

Nystrom, P. C. and Starbuck, W. H. (1984). 'To Avoid Organizational Crises, Unlearn', Organizational Dynamics, 12(4): 53-65.

Ohmae, K. (1989). 'Managing in a Borderless World', Harvard Business Review, 67(3): 152-161.

Osland, J. and Bird, A. (2000). 'Beyond Sophisticated Stereotyping: Cultural Sensemaking in Context', Academy of Management Executive, 14(1): 65-77.

Paul, H. (2000). 'Creating a Mindset', Thunderbird International Business Review, 42(2): 187 200. 
This is the version of the article accepted for publication in The Global Mindset. Advances in International Management published by Emerald doi:10.1016/S1571-5027(07)19002-1

Accepted version downloaded from SOAS Research Online: http://eprints.soas.ac.uk/32166

Perlmutter, H. (1969). 'The Tortuous Evolution of the Multinational Corporation', Columbia Journal of World Business, 4(1): 9-18.

Peyrefitte, J., Fadil, P. A. and Thomas, A. S. (2002). 'The Influence of Managerial Experiences on Large Firm Internationalization', International Journal of Management, 19(3): 495502.

Prahalad, C. K. (1990). 'Globalization: The Intellectual and Managerial Challenges', Human Resource Management, 29(1): 27-37.

Prahalad, C. K. and Bettis, R. A. (1986). 'The Dominant Logic: A New Linkage between Diversity and Performance', Strategic Management Journal, 7: 485-501.

Prahalad, C. K. and Doz, Y. L. (1987). The Multinational Mission: Balancing Local Demands and Global Vision New York: The Free Press.

Pucik, V., Tichy, N. M. and Barnett, C. (1992). Globalizing Management: Creating and Leading the Competitive Organization New York: John Wiley and Sons.

Reuber, A. R. and Fischer, E. (1997). 'The Influence of the Management Team's International Experience on the Internationalization Behaviors of SMEs', Journal of International Business Studies, 28(4): 807-825.

Rhinesmith, S. H. (1992). 'Global Mindsets for Global Managers', Training \& Development, 46(10): 63-69.

Rhinesmith, S. H. (1993). Globalization: Six Keys to Success in a Changing World Alexandria, VA: The American Society For Training and Development.

Rhinesmith, S. H. (1996). A Manager's Guide to Globalization: Six Skills for Success in a Changing World (2nd). New York: McGraw-Hill.

Ricks, D. A., Toyne, B. and Martinez, Z. (1990). 'Recent Developments in International Management Research', Journal of Management, 16(2): 219-253.

Robbins, B. (1992). 'Comparative Cosmopolitanism', Social Text, 31-32: 169-186.

Rosenzweig, P. M. and Singh, J. V. (1991). 'Organizational Environments and the Multinational Enterprise', Academy of Management Review, 16(2): 340-361.

Roth, K. (1995). 'Managing International Interdependence: CEO Characteristics', Academy of Management Journal, 38(1): 200-231.

Rousseau, D. M. (1985). 'Issues of Level in Organizational Research: Multi-Level and CrossLevel Perspectives', Research in Organizational Behavior, 7: 1-37. 
This is the version of the article accepted for publication in The Global Mindset. Advances in International Management published by Emerald doi:10.1016/S1571-5027(07)19002-1

Accepted version downloaded from SOAS Research Online: http://eprints.soas.ac.uk/32166

Sambharya, R. B. (1996). 'Foreign Experience of Top Management Teams and International Diversification Strategies of U.S. Multinational Corporations', Strategic Management Journal, 17(9): 739-746.

Sanders, W. G. and Carpenter, M. A. (1998). 'Internationalization and Firm Governance: The Roles of CEO Compensation, Top Team Composition, and Board Structure', Academy of Management Journal, 42(2): 158-178.

Schneider, S. C. and Angelmar, R. (1993). 'Cognition in Organizational Analysis: Who's Minding the Store?' Organization Studies, 14(3): 347-374.

Schroder, H., Driver, M. and Streufert, S. (1967). Human Information Processing. Individuals and Groups Functioning in Complex Social Situations New York: Holt, Rinehart and Winston, Inc.

Schroder, H. M. and Suedfeld, P. (eds) (1971). Personality Theory and Information Processing. New York: Ronald Press.

Schwenk, C. R. (1984). 'Cognitive Simplification Processes in Strategic Decision-Making', Strategic Management Journal, 5: 111-128.

Sieber, J. E. and Lanzetta, J. T. (1964). 'Conflict and Conceptual Structure as Determinants of Decision Making Behavior', Journal of Personality and Social Psychology, 32: 622-641.

Smircich, L. and Stubbart, C. (1985). 'Strategic Management in an Enacted World', Academy of Management Review, 10(4): 724-736.

Sproull, L. S. (1984). 'The Nature of Managerial Attention', Advances in Information Processing in Organizations, 1: 9-27.

Srinivas, K. M. (1995). 'Globalization of Business and the Third World: Challenge of Expanding the Mindsets', Journal of Management Development, 14(3): 26-49.

Streufert, S. and Nogami, G. (1989). 'Cognitive Style and Complexity: Implications for I/O Psychology'. In Cooper, C. L. and Robertson, I. (eds) International Review of Industrial and Organizational Psychology. Chichester, UK: Wiley, pp. 93-143.

Streufert, S., Pogash, R. M. and Piasecki, M. T. (1988). 'Simulation Based Assessment of Managerial Competence: Reliability and Validity', Personnel Psychology, 41: 537-555.

Streufert, S. and Streufert, S. C. (1978). Behavior in the Complex Environment Washington, DC: Winston.

Streufert, S., Streufert, S. C. and Castore, C. H. (1968). 'Leadership in Negotiations and the Complexity of Conceptual Structure', Journal of Applied Psychology, 52(3): 218-223.

Streufert, S. and Swezey, R. W. (1986). Complexity, Managers, and Organizations Orlando, FL: Academic Press. 
This is the version of the article accepted for publication in The Global Mindset. Advances in International Management published by Emerald doi:10.1016/S1571-5027(07)19002-1

Accepted version downloaded from SOAS Research Online: http://eprints.soas.ac.uk/32166

Stubbart, C. I. (1989). 'Managerial Cognition: A Missing Link in Strategic Management Research', Journal of Management Studies, 26(4): 325-347.

Sweet, S., Roome, N. and Sweet, P. (2003). 'Corporate Environmental Management and Sustainable Enterprise: The Influence of Information Processing and Decision Styles', Business Strategy and the Environment, 12(4): 265-277.

Taylor, S., Levy, O., Boyacigiller, N. and Beechler, S. (forthcoming). 'Employee Commitment in MNCs: Impacts of Organizational Culture, HRM and Top Management Orientations', International Journal of Human Resource Management.

Thomas, J. B., Clark, S. M. and Gioia, D. A. (1993). 'Strategic Sensemaking and Organizational Performance: Linkages Among Scanning, Interpretation, Action, and Outcomes', Academy of Management Journal, 36(2): 239-270.

Tichy, N. M., Brimm, M., Charan, R. and Takeuchi, H. (1992). 'Leadership Development as a Lever for Global Transformation'. In Pucik, V., Tichy, N. M. and Barnett, C. (eds) Globalizing Management: Creating and Leading the Competitive Organization. New York: John Wiley and Sons, pp. 47-60.

Tihanyi, L., Ellstrand, A. E., Daily, C. M. and Dalton, D. R. (2000). 'Composition of the Top Management Team and Firm International Diversification', Journal of Management, 26(6): 1157-1177.

Tseng, C.-H., Tansuhaj, P. S. and Rose, J. (2004). 'Are Strategic Assets Contributions or Constraints for SMEs to Go International? An Empirical Study of the US Manufacturing Sector', Journal of American Academy of Business, 5(1-2): 246-254.

Vertovec, S. and Cohen, R. (eds) (2002a). Conceiving Cosmpolitanism: Theory, Context, and Practice. Oxford: Oxford University Press.

Vertovec, S. and Cohen, R. (2002b). 'Introduction: Conceiving Cosmpolitanism'. In Vertovec, S. and Cohen, R. (eds) Conceiving Cosmpolitanism: Theory, Context, and Practice. Oxford: Oxford University Press, pp. 1-22.

Von Glinow, M. A. (2001). 'Future Issues in Global Leadership Development'. In Mendenhall, M. E., Kühlmann, T. M. and Stahl, G. K. (eds) Developing Global Business Leaders. London: Quorum Books, pp. 264-271.

Walsh, J. P. (1995). 'Managerial and Organizational Cognition: Notes from a Trip Down Memory Lane', Organization Science, 6(3): 280-321.

Wang, E. T. G. (2003). 'Effect of the Fit Between Information Processing Requirements and Capacity on Organizational Performance', International Journal of Information Management, 23(3): 239-247. 
This is the version of the article accepted for publication in The Global Mindset. Advances in International Management published by Emerald doi:10.1016/S1571-5027(07)19002-1

Accepted version downloaded from SOAS Research Online: http://eprints.soas.ac.uk/32166

Wang, P. and Chan, P. S. (1995). 'Top Management Perception of Strategic Information Processing in a Turbulent Environment', Leadership \& Organization Development Journal, 16(7): 33-43.

Weick, K. E. (1979). 'Cognitive Processes in Organizations'. In Staw, B. (ed) Research in Organizational Behavior. Greenwich, CT: JAI Press, pp. 41-74.

Weick, K. E. and Bougon, M. G. (1986). 'Organizations as Cognitive Maps: Charting Ways to Success and Failure'. In Sims, H. P. and Gioia, D. A. (eds) The Thinking Organization: Dynamics of Organizational Social Cognition. San Francisco: Jossey-Bass Publishers, pp. 102-135.

Yeoh, P.-L. (2004). 'International Learning: Antecedents and Performance Implications among Newly Internationalizing Companies in an Exporting Context', International Marketing Review, 21(4): 511-535. 